adding ethanol, and are investigating further modifications in the hope of finding a simple yet reliable method for assessing fetal pulmonary maturity in routine clinical practice. At present, in our opinion, biochemical assay of amniotic fluid lecithin level provides the most reliable assessment.

We thank Mrs. Pam Welten for expert technical help. We are grateful to the medical and nursing staff of the Maternity Hospital, Cardiff, for the collection of amniotic fluid samples, and to the Association of Commonwealth Universities for a scholarship to S.G.B.

\section{References}

Adams, F. H., and Fujiwara, T. (1963). Fournal of Pediatrics, 63, 537. Adams, F. H., Fuiiwara, T., Emmanouilides, G., and Scudder, A. (1965). Fournal of Pediatrics, 66, 357.
Avery, M. E., and Mead, J. (1959). American fournal of Diseases of Children, $97,517$.

Bhagwanani, S. G., Fahmy, D., and Turnbull, A. C. (1972a). Lancet, 1, 159.

Bhagwanani, S. G., Fahmy, D., and Turnbull, A. C. (1972b). Lancet, 2, 66. Brumley, G. W., Chernick, V., Hodson, W. A., Normand, A. F., and Avery, M. E. (1967a). Fournal of Clinical Investigation, 46, 863.

Brumley, G. W., Hodson, W. A., and Avery, M. E. (1967b). Pediatrics,

Clements, J. A., et al. (1972). New England fournal of Medicine, 286, 1077. Fozzard, C. E., and White, R. H. (1972). Lancet, 1, 442.

Fujiwara, T., Adams, F. H., and Scudder, A. (1964). Fournal of Pediatrics, 65,824 .

Gluck, L., Kulovich, M. V., Borer, R. C. jun., Anderson, G. G., and Spellacy, W. N. (1971). American Fournal of Obstetrics and Gynecology, 106,440 . Gluck, L., Sribney, M., and Kulovich, M. V. (1967). Paediatric Research,
1, 247.

Nelson, G. H. (1972). American fournal of Obstetrics and Gynecology, 112, 827.

Prattle, R. E. (1958). Proceedings of the Royal Society. Series B. Biological Sciences, 148, 217.

Scarpelli, E. M. (1967). Pediatrics, 40, 951.

\title{
Hydroxyurea, Leucopheresis, and Splenectomy in Chronic Myeloid Leukaemia at the Problastic Phase
}

\author{
L. SCHWARZENBERG, G. MATHÉ, P. POUILLART, R. WEINER, J. LOCOUR, J. GENIN, \\ M. SCHNEIDER, FRANCOISE DE VASSAL, M. HAYAT, J. L. AMIEL, J. R. SCHLUMBERGER, \\ C. JASMIN, C. ROSENFÉLD
}

British Medical fournal, 1973, 1, 700-703

\section{Summary}

Forty-three patients with chronic myeloid leukaemia have been treated with hydroxyurea in order to be subjected to leucopheresis for white cell transfusions. Hydroxyurea decreases leucocytosis when it is administered and the blood granulocyte number increases soon after the drug is stopped. The survival of the patients is not different from the survival of the patients treated with conventional chemotherapy (busulphan, mitobronitol) and it is superior to the survival of patients treated with external radiotherapy or with ${ }^{32}$. Half of the patients were subjected to splenectomy during first remission for a phase II trial. They were not randomized, but the distribution according to age was similar in the two groups. A slight difference appears in favour of splenectomy so far as survival is concerned, but there were three postoperative deaths out of 18 patients. We conclude that a

\footnotetext{
Unité Fred-Siguier, Institut de Cancérologie et d'Immunogénetique (I.C.I.G.), Hopital Paul-Brousse, 14 et 16 Avenue Paul-Vaillant(I.C.I.G.), Hopital Paul-Brousse, 14

L. SCHWARZENBERG, M.D.

G. MATHE, M.D.

P. POUILLART, M.D.

R. WEINER, $M$.

Service d'Hematologie et autres services de l'Institut GustaveRoussy, 16 Bis Avenue Paul-Vaillant-Couturier, 94800 Villejuif, France

J. LACOUR, M.D.

J. GENIN, M.D.

M. SCHNEIDER, M.D.

FRANCCOISE DE VASSAL, M.D.

M. HAYAT, M.D.

J. L. AMIEL, M.D.

I. R. SCHLUMBERGER, M.D.

C. JASMIN, M.D.

C. ROSENFELD, M.D.
}

phase II trial on the value of splenectomy is indicated ethically, but that the patients should be operated on and nursed in a microbiologically controlled environment.

\section{Introduction}

During the past 10 years a few malignant diseases of the haemopoietic and lymphatic systems have been the subject of considerable therapeutic advance. In two of them-acute lymphatic leukaemia (Mathé et al., 1973) and Hodgkin's disease (Mathé and Tubiana, 1973)-the possibility of a cure is nearing reality. On the other hand, the prognosis of chronic myeloid leukaemia (C.M.L.) seems to have changed very little. This is all the more disappointing as "myeloid" cells that proliferate at the beginning of the disease are very sensitive to radiotherapy (Bauer and Hartweg, 1962; H. Schoen and $\mathbf{R}$. Bauer, personal communication) and to several drugs which have become available in the past two decades-namely busulphan (Bernard et al., 1955; Galton and Till, 1955), mitobronitol (Sellei and Eckhardt, 1963; Mathé et al., 1964), demecolcine (Moeschlin et al., 1954; Cattan et al., 1966), piposulfan ( $N, N^{n}$-bis-(3-methanesulfonoxypropanoyl) piperazine) (Kenis, 1968), and hydroxyurea (Fishbern et al., 1964; Cat$\tan$ et al., 1966). The explanation for this lack of progress appears to be the inevitable occurrence of a blastic proliferation ("blastic crisis") in patients who do not die from therapeutic or other medical accidents. This means that C.M.L. can be considered as the forerunner of an acute leukaemia. This concept underlies the strategy of the current E.O.R.T.C. "leukemia and hematosarcoma" group C.M.L. therapy protocol, which is designed to test the value of prophylactic antiblastic treatment.

The main object of this study was to settle a logistic and ethical problem which arose when Freireich et al. (1964) and our group (Schwarzenberg et al., 1965) showed that C.M.L. white cell transfusates contain physiologically active leucocytes that can cure agranulocytosis. The question then 
arose, Does leucopheresis harm patients with C.M.L.? The only way to get enough C.M.L. cells for transfusion in an active medical oncology service is to treat C.M.L. with hydroxyurea so that a high circulating leucocyte count develops when the course is interrupted. Hence it was important to find out whether a protocol combining hydroxyurea and leucopheresis does any harm to the patient and whether it is less effective than conventional radiotherapy or busulphan treatment.

The second object was to conduct at the same time a phase I trial on the effect of splenectomy. As it is known that splenectomy when performed during an active phase of the disease is very often complicated by thrombocytosis ( $P$. Chevallier, personal communication) we proposed to do the splenectomy at the beginning of the first remission.

\section{Methods and Patients}

The following protocol was used. (a) The first and subsequent active phases of the disease were treated with hydroxyurea at a dose of 1,500-2,500 mg/day for adults until apparent remission, and then $500 \mathrm{mg} /$ day as a maintenance dose. (b) When it was known that the patient's white cells would be needed as donor cells maintenance treatment was stopped one month beforehand in order for the peripheral blood leucocyte count to rise to $60,000 / \mathrm{mm}^{3}$. The patients (whose consent was obtained after the basis of the treatment had been explained to them) were then subjected to a series of leucophereses (fewer than $10^{11}$ cells). (c) Splenectomy was performed during the first remission, provided that there were no contraindications and the patients and their general practitioners agreed to this procedure.

Forty-three patients ( 22 male, 21 female) aged 13 to 69 years were treated with hydroxyurea. Their age distribution is shown in table I. Of the 43 patients 36 were subjected to repeated leucopheresis, 7 having presented contraindications (age, cardiovascular state), and 18 were splenectomized.

TABle I-Age Distribution of the 43 Patients

\begin{tabular}{ll|c|c|c|c|c|c}
\hline Age in years ... & $\ldots$ & $13-20$ & -30 & -40 & -50 & -60 & -69 \\
No. of patients & $\cdots$ & 6 & 7 & 5 & 8 & 12 & 5 \\
\hline
\end{tabular}

\section{Results and Discussion}

\section{HYDROXYUREA TREATMENT}

So-called "complete remission" (blood and marrow unrecognizable as leukaemic except by chromosome examination) was obtained in only one case with hydroxyurea, in contrast to the findings of other studies with busulphan (unpublished data), mitobronitol (Mathé et al., 1964), demecolcine (Cattan et al., (1966), and piposulfan (unpublished data) table II. In

TABLE II-Incidence of Remissions induced with Hydroxyurea compared with Other Drugs (Personal Experience)

\begin{tabular}{ll|c|c|c|c|c}
\hline \multicolumn{1}{c|}{ Drugs } & $\begin{array}{c}\text { No. of } \\
\text { Courses }\end{array}$ & $\begin{array}{c}\text { Complete } \\
\text { Remission }\end{array}$ & $\begin{array}{c}\text { Incomplete } \\
\text { Remission }\end{array}$ & Failure & $\begin{array}{c}\text { Fatal } \\
\text { Bone } \\
\text { Marrow } \\
\text { Aplasia }\end{array}$ \\
\hline Hydroxyurea* $_{\text {Busulphant }}$ & $\cdots$ & 43 & 1 & 39 & 2 & 1 \\
Mitobronitol $_{\text {Demecolcine }}$ & $\cdots$ & 12 & 18 & 12 & 7 & 1 \\
Piposulfan $^{11}$ & $\cdots$ & 7 & 3 & 6 & 2 & 1 \\
\hline
\end{tabular}

* 1,500-2,500 mg/day until remission, then $500 \mathrm{mg} /$ day.

4-6 mg/day until remission.

$250-500 \mathrm{mg} /$ day for 7 days every fortnight.

1 1-3 $\mathrm{mg} /$ day until remission.
39 cases an "incomplete" remission was obtained, defined as a discrete leucocytosis with a few immature granulocytes still present in the blood. In seven cases the marrow was still a little more hyperplastic than normal on cytological examination, and in five the spleen was still palpable. The $\mathrm{Ph}_{1}$ chromosome was detected by bone marrow culture in all cases.

A state of almost complete remission can be maintained for many months if hydroxyurea is given permanently at a dose needed to keep the patient symptom-free, as was observed in the patients who were not subjected to leucopheresis.

\section{LEUCOPHERESIS IN HYDROXYUREA-TREATED PATIENTS}

In the 36 patients who had repeated leucopheresis the leucocytosis and myelaemia were cyclic, relating to the administration of the drug; administration was deliberately stopped when the white cells were needed for transfusion. Examples of such cyclic behaviour of leucocytosis are shown in figs. 1 and 2 . During such a cycle the patients were subjected to 5 to 60 leucophereses, at each of which between $9^{10}$ and $10^{11}$ granulocytes were removed. The very slight, non-therapeutic effect of leucopheresis on the blood leucocytosis is shown in fig. 3.

The arguments for and against the use of a protocol which allows C.M.L. to relapse for the convenience of the physician must be evaluated. The immense value of C.M.L. granulocyte transfusions in treating septicaemia complicating marrow aplasia is illustrated in table III. The only approach is

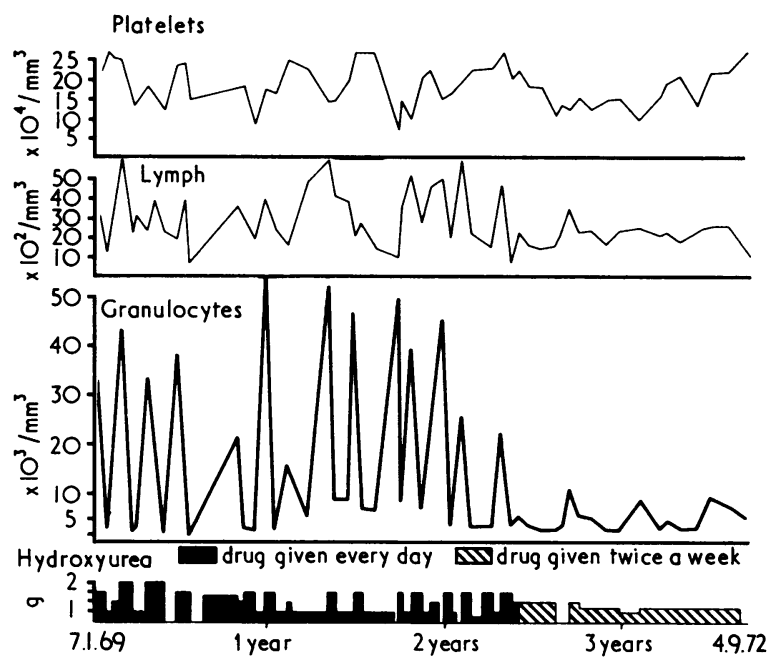

FIG. 1-Example of cyclic administration of hydroxyurea; the drug was deliberately stopped when white cells were needed.

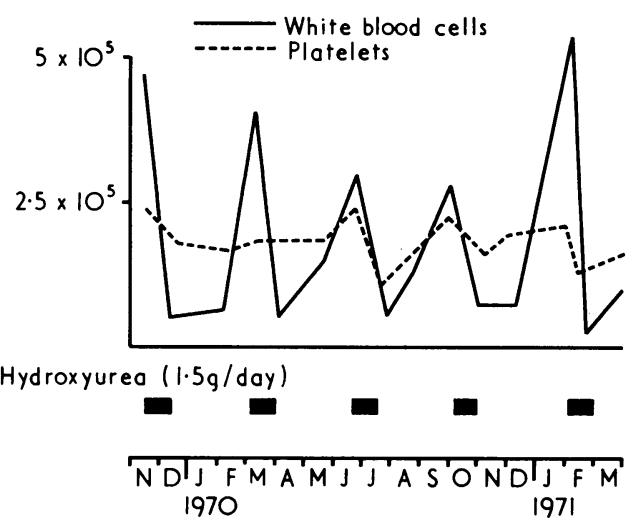

FIG. 2-Trend in white blood cell and platelet levels in 50-year-old woman treated with hydroxyurea $1.5 \mathrm{~g}$ daily. 


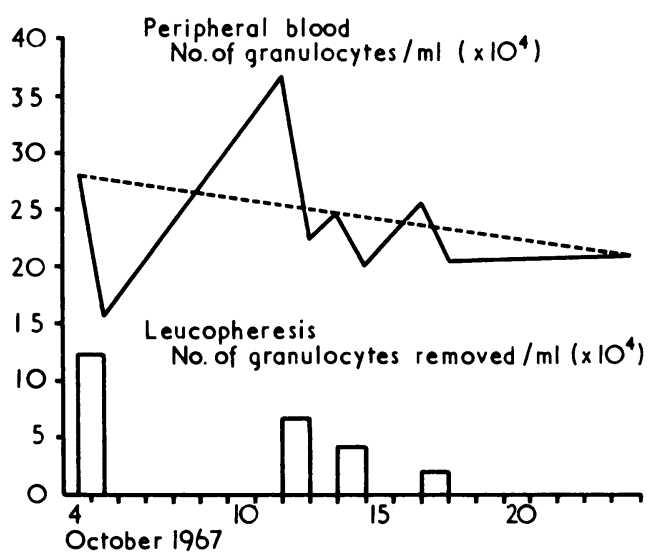

FIG. 3-Effect of leucopheresis on blood leucocytosis.

TABLB III-Usefulness of C.M.L. White Cell Transfusions from Patients Submitted to Present Protocol

\begin{tabular}{|c|c|c|c|}
\hline \multirow{2}{*}{$\begin{array}{c}\text { No. of White Cell } \\
\text { Transfusions }\end{array}$} & \multirow{2}{*}{$\begin{array}{c}\text { No. of } \\
\text { Granulocytes } \\
\text { Infused }\end{array}$} & \multicolumn{2}{|c|}{ Results in 315 Patients } \\
\hline & & $\begin{array}{l}\text { Cure of } \\
\text { Infection }\end{array}$ & $\begin{array}{c}\text { Increase in } \\
\text { Leucocyte Count }\end{array}$ \\
\hline 990 & $749 \times 10^{11}$ & $164(52 \%)$ & $120(38 \%)$ \\
\hline
\end{tabular}

to ask whether there is any evidence that the protocol is harmful; the patients' potential as leucocyte donors is beyond doubt. In no instance did the haemoglobin level fall more than 1 to $1.5 \mathrm{~g} / 100 \mathrm{ml}$ when hydroxyurea was stopped, which is compatible with a satisfactory clinical state.

The cumulative duration of survival of patients submitted to the hydroxyurea-leucopheresis protocol was no different from the survival times of patients treated conventionally with busulphan (Haut et al., 1961; Medical Research Council, 1968) and mitobronitol (Co-operative Study Group, 1972), which were only slightly longer than those obtained by irradiation of the spleen (Medical Research Council, 1968) and therapy with ${ }^{32} \mathrm{P}$ (Reinhard et al., 1959), the latter survival time being no different from that of untreated patients (Minot et al., 1924). The median survival time in the present series was 39.6 months, while in the conventional busulphan chemotherapy trials it was about $\mathbf{4 0}$ months (fig. 4). In conclusion, this protocol, which allows us to use C.M.L. patients with agranulocytosis complicated by septicaemia, works as well as con-

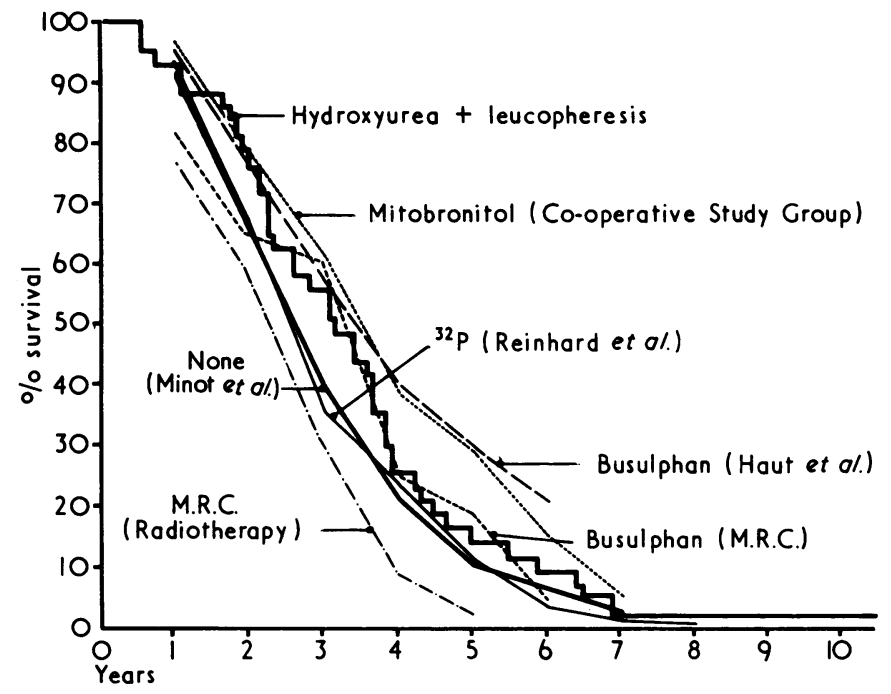

FIG. 4-Cumulative survival time of patients subjected to hydroxyurea + leucopheresis compared with survival of patients submitted to other protocols. ventional treatment, which deprives the haemato-oncological intensive care units of the best source of leucocytes for granulocyte transfusions.

The findings presented here are limited to patients treated in specialized centres, and the toxicity problems in these centres seem to be identical, as is shown in table IV. We believe that these results favour the use of hydroxyurea compared with other forms of therapy when all patients treated in all centres are considered. During the past few years we have received in our haemato-oncological intensive care unit five patients with busulphan aplasia; three of them died. In our experience treatment of C.M.L. with busulphan is at present the most frequent cause of death from irreversible marrow aplasia.

TABLE IV-Toxicity of Hydroxyurea + Leucopheresis compared with that of Other Treatments

\begin{tabular}{|c|c|c|}
\hline & Deaths & Other Manifestations \\
\hline $\begin{array}{l}\text { Hydroxyurea }+ \\
\text { Leucopheresis in our } \\
\text { centre } \\
\text { Mitobronitol in our } \\
\text { centre } \\
\text { Busulphan in our } \\
\text { centre } \\
\text { Treated in other } \\
\text { hospitals }\end{array}$ & $\begin{array}{l}1 / 43^{*} \\
1 / 12 \\
1 / 41 \\
3\end{array}$ & $\begin{array}{l}\text { Amenorrhoea, melanoderma, pulmonary } \\
\text { fibrosis } \\
2 \text { Long-term aplasias in one year }\end{array}$ \\
\hline
\end{tabular}

* The drug had to be administered at a higher dose and for a prolonged period because of severe splenomegaly.

\section{SPLENECTOMY}

Of the 43 patients 18 were splenectomized during their first remission and 25 (or their doctors) refused this operation. The age distributions of the two groups of patients were very similar (fig. 5). The cumulative duration of survival was a little longer in the splenectomy group (median 43 months, mean 51 months) than in the non-splenectomy group (median 37 months, mean $37 \cdot 1$ months), but one must take into account three postoperative deaths due to hospital infections, and in two cases the spleen was infiltrated with blast cells (fig. 6). So far as other complications of splenectomy are con-

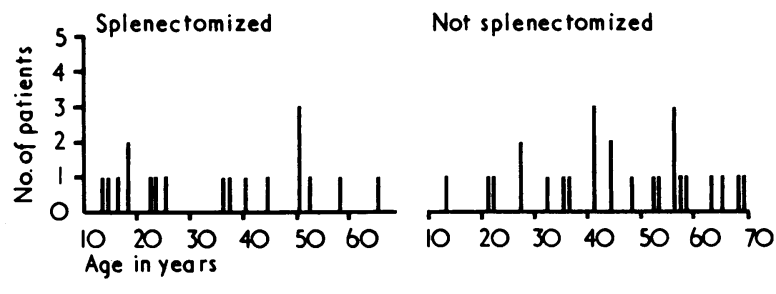

FIG. 5-Age distribution of patients subjected to splenectomy and of those who refused the operstion.

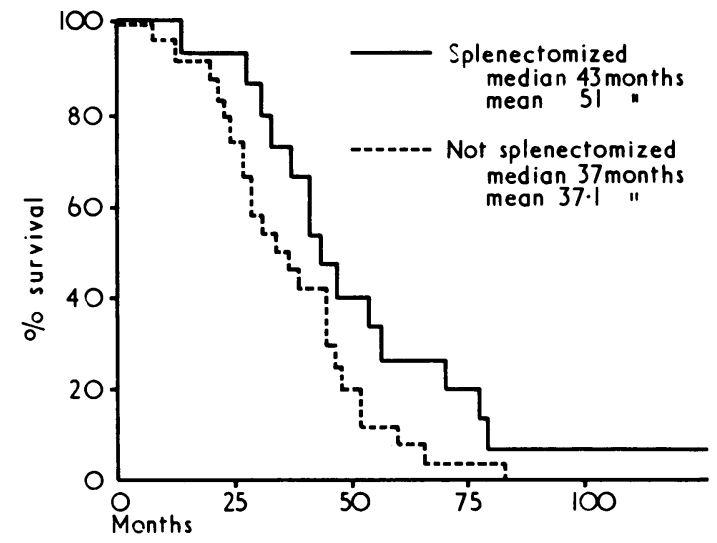

FIG. 6-Cumulative survival times of the splenectomized and non-splenctomized patients (evaluable cases only). 
cerned there were six cases of thrombocythaemia. This was easy to control in four (the increased number of platelets was not followed) and was complicated by thrombosis in two (thrombosis was controlled by heparin). In conclusion, a beneficial effect of splenectomy is still equivocal after this phase I trial. The proportion of postoperative deaths (three out of 18 has to be reduced if the procedure is to be advocated. We hope to achieve this when patients can be operated on and nursed for one month in an aseptic environment, which will be possible in the "microbiological gradient service" being built in the Hospital Paul-Brousse at Villejuif. One of the objectives of splenectomy was to completely eradicate the disease; the persistence of the $\mathrm{Ph}_{1}$ chromosome after surgery, however, shows that this aim was not attained. Another objective was to prevent the well known splenic complication arising during the blastic crisis. In fact, all patients who did not die after splenectomy or aplasia died from a blastic crisis, which is the inevitable end-phase of C.M.L. But we have to evaluate the effect of splenectomy on the overall results of the treatment of blastic crisis in C.M.L.; table $\mathrm{V}$ and fig. 7

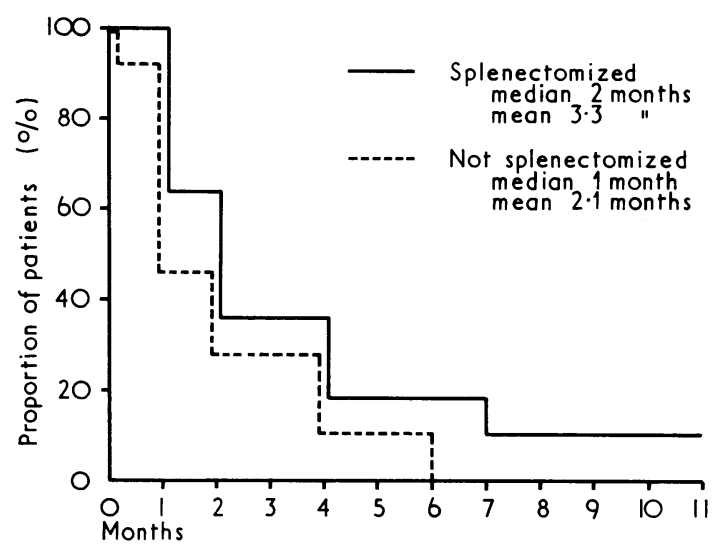

FIG. 7-Cumulative duration of survival from onset of blastic crisis in splenectomized and non-splenectomized patients.
TABLE V-Effect of Splenectomy on Course of Blastic Crisis

\begin{tabular}{|c|c|c|}
\hline & Splenectomy & No Splenectomy \\
\hline 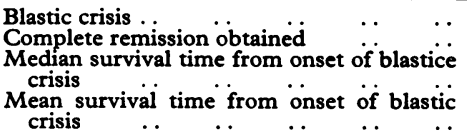 & $\begin{array}{l}13 / 15 \\
2 / 13 \\
2 \text { Months } \\
\text { 3.3 Months }\end{array}$ & $\begin{array}{c}19 / 24 \\
3 / 19 \\
1 \text { Month } \\
2 \cdot 1 \text { Months }\end{array}$ \\
\hline
\end{tabular}

show that there were no differences in the development of blastic crises or in the frequency of remissions but that there was a slight difference in survival from the onset of blastic crisis.

\section{References}

Bauer, R., and Hartweg, H. (1962). Fortschritte auf dem Gebiete der Röntgenstrahlen und der Nuklearmedizin, 96, 276.

Bernard, J., Mathé, G., and Najean, Y. (1955). Semaine des Hôpitaux de Paris, 59, 3082.

Cattan, A., et al. (1966). Semaine des Hôpitaux de Paris, 42, 2966.

Co-operative Study Group on Dibromomannitol (1972). Haematologica. In press.

Fishbern, W. N., Carbone, P. P., Freireich, E. J., Misra, D., and Frei, E. (1964). Clinical Pharmacology and Therapeutics, 5, 574.

Freireich, E. J., et al. (1964). Annals of the New York Academy of Sciences, 113,1081 .

Galton, D. A. G., and Till, M. (1955). Lancet, 1, 425.

Haut, A., Abbott, W. S., Wintrobe, M. M., and Cartwright, G. H. (1961)., Blood, 17, 1 .

Kenis, Y. (1968). Cancer Chemotherapy Reports, 52, 433.

Mathé, G., et al. (1973). In Acute Leukemias, Nomenclature, Classification, Clinical Trials, Methodology and Actuarial Results, ed. G. Mathé, P. Pouillart, and L. Schwarzenberg, vol. 1. Heidelberg, Springer.

Mathé, G., Schneider, M., Cattan, A., Schwarzenberg, L., and Amiel, J. L. (1964). Presse Médicale, 72, 2135.

Mathé, G., and Tubiana, M. (1973). In Series Hematologica. Copenhagen, Munksgaard. In press.

Medical Research Council's Working Party for Therapeutic Trials in Leukemia (1968). British Modical fournal, 1, 201.

Minot, G. R., Buckman, T. E., and Isaacs, R. (1924). fournal of the American Medical Association, 82, 1489.

Moeschlin, S., Meyer, H., and Lichtman, A. (1954). In Ciba Foundation Symposium on Leukemia Research, p. 216 Boston, Little, Brown.

Reinhard, E. H., Neely, C. L., and Samples, D. M. (1959). Annals of Internal Medicine, 50, 942.

Schwarzenberg, L., et al. (1965). Israel fournal of Medical Sciences, 1, 925.

Sellei, C., and Eckhardt, S. (1963). Revue Francaise d'Etudes Cliniques et Biologiques, 8, 483.

\title{
Incidence of Coeliac Disease in the West of Ireland
}

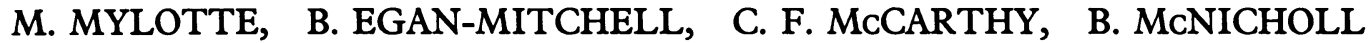

British Medical fournal, 1973, 1, 703-705

\section{Summary}

During an 11-year period the incidence of coeliac disease presenting in children in the West of Ireland has been found to be 1 in 597 . When allowance is made for presentation of the disease in adult life the incidence may be as high as 1 in 303. These figures are much higher than those reported for Britain.

\footnotetext{
Departments of Gastroenterology and Paediatrics, Regional Hospital and University College, Galway M. MYLOTTE, M.B., B.A.O., Research Fellow B. EGAN-MITCHELL, M.B., D.C.H., Research Fellow C. F. MCCARTHY, M.D., F.R.C.P.I., Associate Professor of Medicine B. MCNICHOLL, M.D., F.R.C.P., Professor of Paediatrics
}

\section{Introduction}

Estimates of the incidence of coeliac disease vary considerably. In 1950 Davidson and Fountain estimated the incidence to be about 1 in 8,000 in England and Wales and 1 in 4,000 in Scotland. Carter et al. (1959), in London, found an incidence of between 1 in 2,000 and 1 in 6,000, and McCrae (1969) calculated the incidence at 1 in 1,850 in Edinburgh. We report a much higher incidence in the West of Ireland.

\section{Site of Study}

The Regional Hospital, Galway, is the teaching hospital for University College, Galway. It is a 700-bed general hospital with a 50-bed paediatric unit. The paediatric unit has had a special interest in coeliac disease since its establishment in 1956. In 1969 a gastrointestinal unit was opened and, from this, knowledge of the occurrence of coeliac disease in adults was 